\title{
Identification of a Pathway from the Retina to Koniocellular Layer K1 in the Lateral Geniculate Nucleus of Marmoset
}

\author{
Kumiko A. Percival, ${ }^{1,2}$ Amane Koizumi, ${ }^{4,5}$ Rania A. Masri, ${ }^{1}$ Péter Buzás, ${ }^{6}$ Paul R. Martin, ${ }^{1,2,3}$ and Ulrike Grünert ${ }^{1,2,3}$ \\ ${ }^{1}$ Departments of Ophthalmology and Save Sight Institute, ${ }^{2}$ Australian Research Council Centre of Excellence in Vision Science, and ${ }^{3}$ School of Medical \\ Sciences, The University of Sydney, Sydney, NSW 2000, Australia, ${ }^{4}$ Department of Cell Physiology, National Institute for Physiological Sciences, Myodaiji, \\ Okazaki, 444-8585, Japan, ${ }^{5}$ Department of Physiological Sciences, School of Life Science, The Graduate University for Advanced Studies (SOKENDAI), \\ Okazaki 444-8787, Japan, and ' Institute of Physiology, Medical School, University of Pécs, 7624 Pécs, Hungary
}

Three well characterized pathways in primate vision (midget-parvocellular, parasol-magnocellular, bistratified-koniocellular) have been traced from the first synapse in the retina, through the visual thalamus (lateral geniculate nucleus, LGN), to the visual cortex. Here we identify a pathway from the first synapse in the retina to koniocellular layer K1 in marmoset monkeys (Callithrix jacchus). Particlemediated gene transfer of an expression plasmid for the postsynaptic density 95-green fluorescent protein (PSD95-GFP) was used to label excitatory synapses on retinal ganglion cells and combined with immunofluorescence to identify the presynaptic bipolar cells. We found that axon terminals of one type of diffuse bipolar cell (DB6) provide dominant synaptic input to the dendrites of narrow thorny ganglion cells. Retrograde tracer injections into the LGN and photofilling of retinal ganglion cells showed that narrow thorny cells were preferentially labeled when koniocellular layer K1 was targeted. Layer K1 contains cells with high sensitivity for rapid movement, and layer K1 sends projections to association visual areas as well as to primary visual cortex. We hypothesize that the DB6-narrow thorny-koniocellular pathway contributes to residual visual functions ("blindsight") that survive injury to primary visual cortex in adult or early life.

Key words: bipolar cells; ganglion cells; koniocellular; parallel pathways; primate retina

\section{Introduction}

Parallel visual pathways are established in the retina and remain segregated within the dorsal lateral geniculate nucleus (LGN) of the thalamus (Lee et al., 2010). Midget ganglion cells send their axons to the parvocellular $(\mathrm{P})$ and parasol cells send their axons to the magnocellular (M) layers of the LGN (Leventhal et al., 1981). The $\mathrm{P}$ pathway serves high-acuity spatial vision and red-green color vision, feeding into the form recognition ("what") pathway. By contrast, signals traveling on the M pathway serve motion and spatial analysis (the "where" pathway). The $\mathrm{P}$ and M pathways are established at the first synapse in the visual pathway. In the $\mathrm{P}$ pathway cones contact midget bipolar cells which in turn contact midget ganglion cells (Kolb and DeKorver, 1991; Calkins et al., 1994); in the M pathway, diffuse bipolar (DB) cells receive input from multiple cones and provide output to parasol cells (Boycott and Wässle, 1991;

Received Oct. 21, 2013; revised Jan. 22, 2014; accepted Jan. 31, 2014.

Author contributions: K.A.P., A.K., P.B., P.R.M., and U.G. designed research; K.A.P., A.K., R.A.M.,P.B.,P.R.M., and U.G. performed research; K.A.P., R.A.M., P.R.M., and U.G. analyzed data; K.A.P., P.R.M., and U.G. wrote the paper.

This work was supported by Project Grants 632640 and 1042609 from the National Health and Medical Research Council of Australia to U.G. and P.R.M., a Grant-in-Aid for Scientific Research from the Ministry of Education, Culture, Sports, Science, and Technology, Japan to A.K., and a Bolyai fellowship of the Hungarian Academy of Sciences to P.B. We thank Carla Abbott, Arzu Demir, Hajime Hirasawa, Ana Lara, Dean Matin, Satoru Moritoh, and Brett Szmajda for assistance with experiments. We are grateful to Patricia Jusuf, who prepared the specimen shown in Figure 1B, Sam Solomon for helpful discussions, and Richard Masland and John McAvoy for comments on the paper. We thank Tetsuo Yamamori and Akiya Watakabe in the Marmoset Research Facility, National Institute for Basic Biology Bioresource Center.

The authors declare no competing financial interests.

Correspondence should be addressed to Dr Ulrike Grünert, The University of Sydney, Macquarie Street, Sydney, NSW 2000, Australia. E-mail: ugrunert@sydney.edu.au.

DOI:10.1523/JNEUROSCI.4491-13.2014

Copyright $\odot 2014$ the authors $\quad 0270-6474 / 14 / 343821-05 \$ 15.00 / 0$
Jacoby and Marshak, 2000; Puthussery et al., 2013). A third retinothalamic pathway involves the koniocellular (K) layers of the LGN (Hendry and Reid, 2000; Casagrande and Xu, 2003). Projections to K layers include ganglion cells called small bistratified cells, which display blue ON/yellow OFF responses (Dacey and Lee, 1994; Martin et al., 1997; Szmajda et al., 2008).

In addition to these three well characterized pathways, at least 12 low-density ganglion cell types that project to the LGN have been identified (Dacey et al., 2003; Crook et al., 2008; Szmajda et al., 2008). These ganglion cell types are difficult to target, and their connectivity within the retina and exact projection within the LGN are not known. Here we trace a pathway from cone photoreceptors through bipolar and ganglion cells to the ventralmost koniocellular layer K1 in the LGN.

\section{Materials and Methods}

Animals. For ganglion cell labeling by particle-mediated gene transfer two female adult marmosets (Callithrix jacchus) were obtained from CLEA Japan and maintained in the National Institute for Basic Biology Bioresource Center. Procedures adhered to the National Institute for Physiological Sciences (NIPS) code of practice for care and use of animals and were approved by the institutional ethics committee of NIPS (No. 11A172) and the National Institutes of Natural Sciences (Nos. 08B005, 10B001).

Tracer injections were performed on five (three male, two female) adult marmosets obtained from the Australian National Health and Medical Research Council (NHMRC) combined breeding facility. Procedures were performed according to NHMRC guidelines for care and use of animals and were approved by the institutional animal ethics committee.

Labeling of ganglion cells by particle-mediated gene transfer. Animals were anesthetized with medetomidine $(0.01 \mathrm{mg} / \mathrm{kg}$, i.m.; Domitor 
Orion) and ketamine (10 mg/kg; Ketalar, Daiichi Sankyo Espha) then overdosed with sodium pentobarbital (80-150 mg/kg; Somnopentyl, Kyoritsu). Organotypic culturing and transfection of retinas was performed as described previously (Koizumi et al., 2007; Jakobs et al., 2008; Moritoh et al., 2013). In brief, quadrants of retina were mounted ganglion cell side up onto a $0.4 \mu \mathrm{m}$ Millicell tissue culture inset (Millipore), and then transfected via particle-mediated transfer using CMV-PSD95-GFP fusion plasmid coated gold microcarriers. The plasmid was a gift from Dr Masaki Fukata (NIPS). The ratio of DNA to the gold microcarriers $(1.6 \mu \mathrm{m})$ was $1.5 \mu \mathrm{g}$ plasmid/1 mg gold. The retina was kept in culture for $3 \mathrm{~d}$.

Tracer injections, photofilling, and LGN reconstruction. Tracer injections followed by photofilling were performed according to methods developed by Dacey et al. (2003). The retinas were those used in Szmajda et al. (2008) and Percival et al. $(2009,2011,2013)$ where detailed procedures are described. The focus of these previous studies was on ganglion cells projecting to layer $\mathrm{K} 3$. To study the injection sites in the LGN, the animal was perfused with $0.9 \%$ saline followed by $4 \%$ paraformaldehyde (PFA) in $0.1 \mathrm{M} \mathrm{PB}$ and $10 \%$ glycerol in $4 \%$ PFA in $0.1 \mathrm{~m}$ phosphate buffer (PB). Serial coronal sections were cut through the thalamus using a freezing microtome. Alternate sections were mounted directly in Mowiol or processed with cresyl violet. Injection sites were reconstructed by outlining the LGN layers and tracing the dense core of the injection site over serial sections.

Immunohistochemistry of gene-gunned retinas and image acquisition. Retinas were fixed in $4 \%$ PFA in PB for $60 \mathrm{~min}$ at $4^{\circ} \mathrm{C}$, and processed for immunofluorescence as described previously (Percival et al., 2011). We used antibodies against CD15 (mouse monoclonal; 1:6; gift from Prof Mai, University of Düsseldorf, Germany) and against the C-terminal binding protein (CtBP2, mouse monoclonal, 1:10,000; Catalog \#612044; BD Biosciences). Secondary antibodies were obtained from Jackson ImmunoResearch.

Images of PSD95-GFP cells were acquired on a confocal microscope (Zeiss LSM 700) equipped with 488, 555, and $639 \mathrm{~nm}$ lasers using PlanApochromat, $20 \times / 0.8$ objective $(2048 \times 2048$ pixels). Images of retrogradely labeled cells were obtained on a Zeiss Axioplan 2 microscope equipped with a digital camera (Axiocam, Zeiss) using a $40 \times$ (PlanNeofluar, $40 \times / 1.3$ oil differential interference contrast, DIC, or $63 \times$ (Plan-Apochromat, $63 \times / 1.4$ Oil DIC) objective. Micrographs of the LGN were acquired as described previously (Szmajda et al., 2008; Percival et al., 2013). Brightness and contrast of digital images were adjusted using Axiovision (Zeiss), Zen (Zeiss), Adobe Photoshop CS4 (v11.0.2), or Imaris (Bitplane) software.

Analysis. Cells were traced in three dimensions from image stacks (Imaris). The number of PSD95-GFP puncta located in a volume immediately surrounding the bipolar axons, and the proportion of the puncta located within a distance of $1 \mu \mathrm{m}$ from the surface area of the bipolar axons, were determined (see Fig. $2 I-K$ ). As control, one image channel was flipped around the $y$-axis and the proportion of puncta close to the surface was determined in this pseudorandom fashion. Voxel colocalization $(x, y: 0.156 \mu \mathrm{m} ; z: 1.065 \mu \mathrm{m})$ was determined using Imaris.

\section{Results}

\section{DB6 cells provide input to narrow thorny ganglion cells}

The focus of our study is on a population of ganglion cells named narrow thorny cells (Dacey et al., 2003; Yamada et al., 2005). Narrow thorny cells have fine, densely branching dendritic trees decorated with numerous dendritic spines. They resemble the G16 (Kolb et al., 1992) or thorny monostratified ganglion cells (Peterson and Dacey, 1999) in human retina. Based on their stratification, narrow thorny cells are likely to receive input via the DB6 cell (Fig. 1A). In marmoset retina, DB6 cells are immunoreactive to antibodies against CD15 (Chan et al., 2001) and immunoelectron microscopy reveals that DB6 axons make synapses with ganglion and amacrine cells (Fig. 1B; Jusuf et al., 2004). The DB6 axon terminals tile the retina in a "loose" mosaic (Fig. 1C). We analyzed the synaptic output of CD15 immunoreactive DB6 cells in preparations containing gene-gunned cells. The bright fluorescent puncta in gene-gunned cells mark excitatory synaptic input (Fig. 2A)

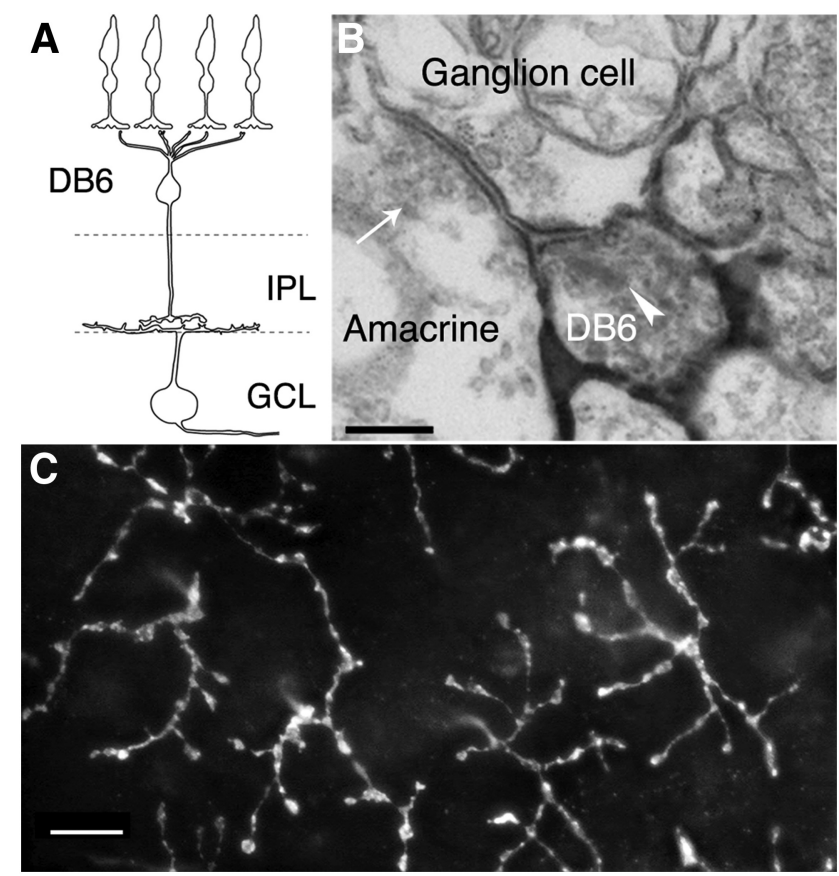

Figure 1. DB6 cells in marmoset retina. $\boldsymbol{A}$, Stratification of DB6 cells in the inner plexiform layer (IPL). GCL, Ganglion cell layer. B, Electron micrograph of a CD15 immunoreactive DB6 axon terminal presynaptic to an amacrine $(\mathrm{AC})$ and a ganglion cell $(\mathrm{GC})$ process. Immunoreactivity is located in the membrane of the cell. Arrowhead indicates synaptic ribbon, arrow points to a conventional synapse from an AC profile onto a GC. C, Fluorescence micrograph showing axon terminals of CD15 immunoreactive DB6 axons in whole mount. Scale bars: $B, 0.2 \mu \mathrm{m} ; \boldsymbol{C}, 10 \mu \mathrm{m}$.

and fainter background labeling arises from PSD95-GFP in transit (Jakobs et al., 2008; Morgan et al., 2008). We confirmed that the PSD95-GFP puncta are the sites of bipolar input by labeling a genegunned retinal quadrant with antibodies against CtBP2, which marks bipolar ribbon synapses (tom Dieck et al., 2005). The majority of PSD95-GFP puncta (average $56.9 \pm 39.8 \%, n=35$ regions from 13 ganglion cells) was located within $1 \mu \mathrm{m}$ of a CtBP2 punctum (Fig. $2 L-N)$. Pseudorandom colocalization reduced this percentage to $39.5 \pm 29.7 \%(p<0.02$, Wilcoxon rank sum test). Consistent findings were obtained previously in other species (Jakobs et al., 2008; Morgan et al., 2008; Bleckert et al., 2013).

We analyzed the DB6 inputs to five narrow thorny cells located at $\sim 6 \mathrm{~mm}$ distance from the fovea. These cells had dendritic field diameters of 245-340 $\mu \mathrm{m}$ and encompassed 24-31 DB6 axon terminals. All DB6 axon terminals showed regions of close association with the dendritic tree of narrow thorny cells (Fig. 2B) and DB6 axons and ganglion cell dendrites were seen to run together (Fig. 2C-H). For three cells we used neighborhood analysis to find local intensity maxima ("spot" detection) and counted the PSD95-GFP puncta located within $1 \mu \mathrm{m}$ of a DB6 axon terminal (Fig. 2I-K). On average, these PSD95-GFP puncta made up $36.8 \%$ (SD 19.8, $n=25$ ) of the PSD95-GFP puncta in the immediate vicinity of an individual axon terminal (Table 1). For two further cells we determined the colocalized pixels between the PSD-GFP and the CD15 immunofluorescence channel (Fig. 2E). We then used spot detection on the colocalization channel and counted colocalized spots relative to all PSD-GFP spots in the immediate vicinity of the DB6 axon terminal. We found that the colocalized spots made up an average $43.3 \%$ ( \pm $18.8 \% \mathrm{SD})$ of the PSD-GFP spots in this region $(n=14$ axon terminals). On average there were 21 ( $\pm 18.1 \mathrm{SD})$ colocalized areas per axon terminal $(n=30)$. 

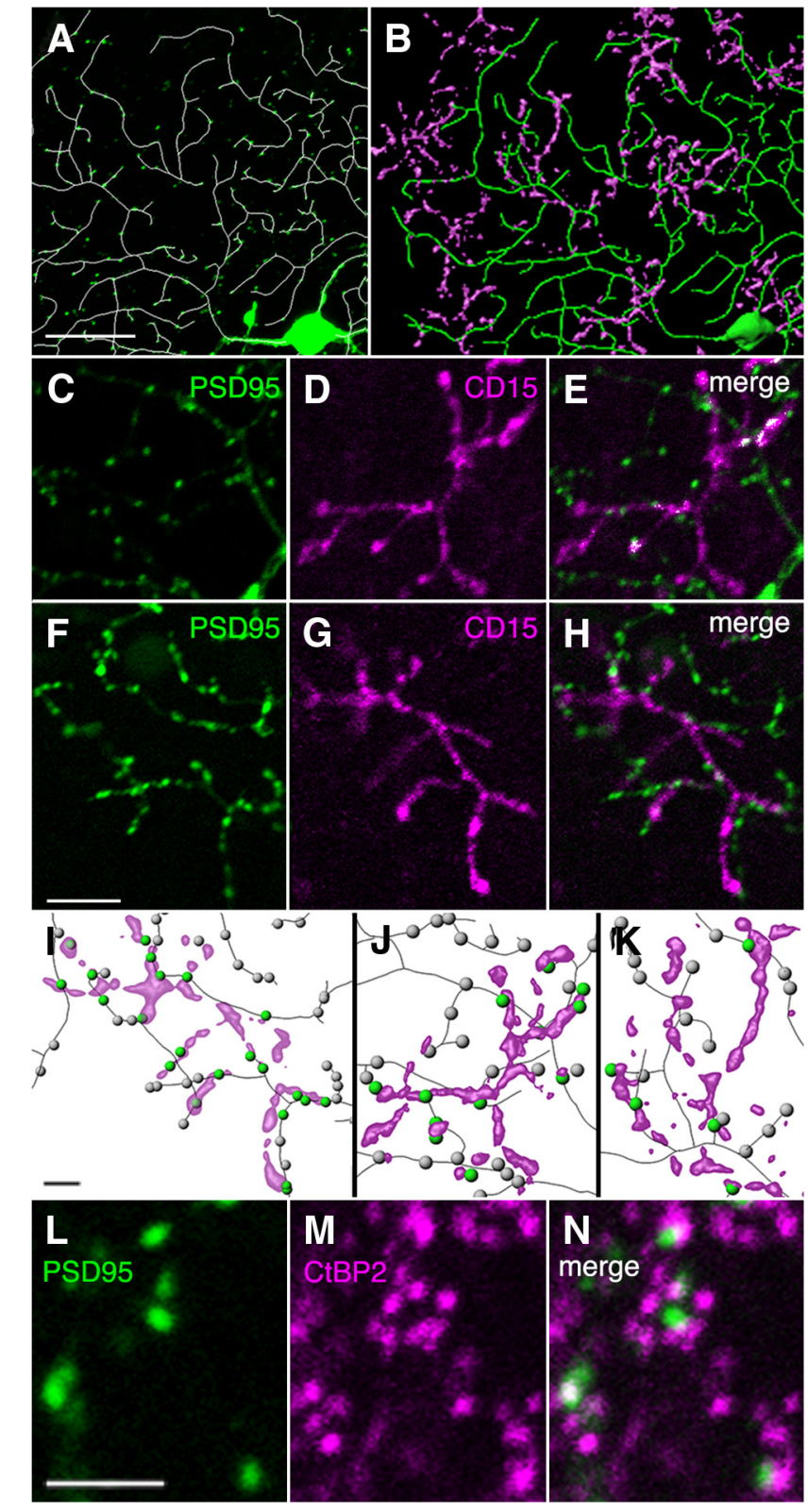

Figure 2. Narrow thorny ganglion cells are connected to DB6 cells. A, PSD95-GFP puncta on dendrites (white lines) of a narrow thorny ganglion cell. $\boldsymbol{B}$, Partial reconstruction of this cell together with DB6 axon terminals. $\boldsymbol{C}-\boldsymbol{H}$, High-resolution images of CD15 labeled DB6 axon terminals (magenta) together with dendritic tree of narrow thorny cells. Single slices of a stack of confocal images. Synaptic zones labeled by PSD95-GFP appear as green puncta. $\boldsymbol{E}, \boldsymbol{H}$, Superimpositions of the two channels, revealing the close association between ganglion cell dendrites and DB6 axons. $\boldsymbol{E}$, Colocalized pixels are white. $\boldsymbol{I}-\boldsymbol{K}$, Reconstructed DB6 axons (magenta) associated with dendrites of narrow thorny cells (black lines). PSD95-GFP puncta located in a volume surrounding an axon terminal are represented as green or gray dots (not to scale). Green dots represent PSD95-GFP puncta that are located within $1 \mu \mathrm{m}$ of the dendrites. $\mathbf{L}-\boldsymbol{N}$, PSD95-GFP (postsynaptic, green) puncta of a ganglion cell dendrite are located opposite presynaptic ribbons (magenta) in gene-gunned tissue processed with antibodies against ribbon marker CtBP2. Scale bars: $\boldsymbol{A}, 30 \mu \mathrm{m} ; \boldsymbol{F}, 10 \mu \mathrm{m} ; \boldsymbol{I}, 5 \mu \mathrm{m} ; \boldsymbol{L}, 3 \mu \mathrm{m}$.

For one narrow thorny cell we measured 12 DB6 axon terminals using both methods; across axon terminals spot counts showed high correlation (correlation coefficient $0.716, p<0.02$ ) indicating both methods give comparable results. For all cells analyzed, the number of colocalized spots was lower when one channel was flipped ( $p<0.02$, Wilcoxon rank sum test).

We compared the connectivity in the DB6 narrow thorny pathway with the well established connectivity in the midget
Table 1. Analysis of bipolar to ganglion cell connectivity

\begin{tabular}{lllc}
\hline & No.1 & No.2 & No.3 \\
\hline $\begin{array}{l}\text { Narrow thorny ganglion cells } \\
\text { DB6 axons analyzed }\end{array}$ & 12 & 9 & \\
$\begin{array}{l}\text { Percentage of PSD95-GFP puncta located } \\
\text { within } 1 \mu \text { m of axon terminal (mean, SD) }\end{array}$ & $38,12.6$ & $20.9,9.8$ & $69.3,10.9$ \\
$\begin{array}{l}\text { Midget ganglion cells } \\
\quad \text { Midget bipolar axons analyzed }\end{array}$ & 3 & & \\
$\begin{array}{l}\text { Percentage of PSD95-GFP puncta located } \\
\text { within } 1 \mu \text { m of axon terminal (mean, SD) }\end{array}$ & $51.7,14.7$ & $43.7,6.0$ & 56.8 \\
\hline
\end{tabular}

Well labeled bipolar axons that overlapped completely with the dendritic field of the ganglion cell were reconstructed; PSD95-GFP puncta in the immediate vicinity of an axon terminal were detected and the percentage of the puncta located $\leq 1 \mu \mathrm{m}$ of the ganglion cell dendrite was determined.

pathway by taking advantage of the fact that OFF midget bipolar cells are labeled in addition to DB6 cells with the antibody against CD15 (Chan et al., 2001). For three midget ganglion cells in peripheral retina, the PSD95-GFP puncta located within $1 \mu \mathrm{m}$ of an OFF midget bipolar axon terminal on average made up $47.8 \%$ (SD 9.9, $n=9$ ) of the PSD95-GFP puncta in the immediate vicinity of this axon terminal (Table 1).

Identification of narrow thorny cells after retrograde labeling Tracer injections into the LGN resulted in retrograde labeling of a variety of ganglion cells. Narrow thorny cells (Fig. $3 A-C$ ) identified at eccentricities between 2.5 and $5 \mathrm{~mm}$ had dendritic field diameters between 100 and $150 \mu \mathrm{m}$, which is similar to that of parasol cells (Ghosh et al., 1996). Indeed, we initially classified some of the narrow thorny cells as parasol cells. Closer analysis revealed (Fig. $3 D, I$ ) that narrow thorny cells, have a higher average dendritic density (dendritic length in $\mu \mathrm{m} / \mathrm{mm}^{2}$; narrow thorny $424.4 \pm 70.6 \mu \mathrm{m}, n=9$; parasol $273.5 \pm 70.2 \mu \mathrm{m}, n=7$, $p<0.02, t$ test), and a higher number of dendritic terminals (including thorns) per $100 \mu \mathrm{m}^{2}$ compared with parasol cells (narrow thorny, $3.7 \pm 1.4, n=9$; parasol $1.2 \pm 0.5, n=7$; $p<$ $0.02, t$ test). The majority $(6 / 9,67 \%)$ of the narrow thorny cells stratified in the ON sublamina of the inner plexiform layer, two cells stratified in the OFF sublamina, and one cell was bistratified with processes in the $\mathrm{ON}$ and the OFF sublamina.

Depending on the site of the tracer injection different types of ganglion cells were retrogradely labeled (Szmajda et al., 2008). Parasol cells dominated when the injection site was centered on the magnocellular layers, whereas narrow thorny cells dominated when the injection was centered on layer K1 (Fig. $3 E-H)$. In two additional experiments, where a small injection into layer $\mathrm{K} 1$ and a larger injection into layer K3 were made, we encountered eight parasol, eight small bistratified, two narrow thorny, and four other wide-field cells. Parasol cells were always labeled because the injecting electrode must pass through the $M$ layers to reach layer K1. One narrow thorny cell was labeled in an experiment where the injection was centered on $\mathrm{K} 3$ but the electrode track included layer K1. We conclude that narrow thorny ganglion cells will be preferentially labeled, if the tracer is injected into layer $\mathrm{K} 1$, but projection of narrow thorny cells to other LGN layers cannot be ruled out. Likewise it appears that additional ganglion cell types project to layer K1 (Szmajda et al., 2008).

The DB6 cells contact all cones in their dendritic field with bias against short-wave sensitive cones (Lee and Grünert, 2007). Thus, narrow thorny cells stratifying in the ON sublamina are likely to display achromatic ON responses. Consistent with this prediction, when we collated results from our previous recording studies in LGN (White et al., 2001; Solomon et al., 2002; Tailby et al., 2008) we found that the great majority of receptive fields 
recorded in layer $\mathrm{K} 1(18 / 22,82 \%)$ show ON-type or ON-OFF-type responses $\left(p<0.05, \chi^{2}\right.$ test). By contrast, ON- and OFF-type responses were evenly balanced in layer $\mathrm{K} 3\left(p>0.5, \chi^{2}\right.$ test $)$, and blue-ON responses were less common in $\mathrm{K} 1(1 / 23,4.3 \%)$ than in $\mathrm{K} 3(77 / 228$, $33.7 \%, p<0.05, \chi^{2}$ test $)$.

\section{Discussion}

Narrow thorny ganglion cells have been identified morphologically in the retinas of a variety of primate species but no electrophysiological recordings from these cells exist, thus their functional role can only be inferred from their retinal circuitry and the properties of their geniculate targets in layer K1.

Our results show that a significant proportion of the bipolar input to narrow thorny cells derives from DB6 cells. We suggest that the DB6 input is the dominant bipolar input to narrow thorny cells because the connections of the other bipolar types stratifying in S4 and S5 are well understood: blue cone bipolar cells contact small bistratified cells (Calkins et al., 1998), rod bipolar cells contact amacrine cells (Grünert and Martin, 1991), and invaginating midget bipolar cells contact ON midget ganglion cells (Kolb and DeKorver, 1991; Calkins et al., 1994).

Our results further indicate that DB6 cells in addition to amacrine cells preferentially contact narrow thorny cells. Other outputs of DB6 cells go to large sparse (Percival et al., 2011, their Fig. 3D) and inner stratifying melanopsin-expressing ganglion cells (Grünert et al., 2011, their Fig. 3) but these cells had on average only $2-3$ presumed contacts per DB6 terminal and thus did not show the same tight connectivity as do narrow thorny cells ( 21 contacts per terminal). The only other ganglion cell type stratifying at the level of the DB6 cells is the small bistratified cell and this cell is known to receive dominant input from blue cone bipolar cells (Calkins et al., 1998).

A large proportion of the PSD95-GFP puncta expressed by narrow thorny cells were located close to DB6 axons; a similar relationship was seen for OFF midget ganglion/OFF midget bipolar cells. A likely explanation for the nonassociated puncta is that synaptic output from weakly labeled DB6 axons was underestimated. Some nonassociated puncta may arise from overexpression of PSD95-GFP.

Electrophysiological recordings show diverse response properties in koniocellular pathways (Irvin et al., 1986; White et al., 2001; Xu et al., 2001; Solomon et al., 2002). Specifically, in marmoset and owl monkey limited recordings from neurons in layers $\mathrm{K} 2$ and $\mathrm{K} 1$ showed receptive fields with high contrast sensitivity, large diameter, high sensitivity to high temporal frequency flicker and negligible responses to short-wave cone stimulation (White et al., 2001; Xu et al., 2001; Solomon et al., 2002). Thus, layers K1
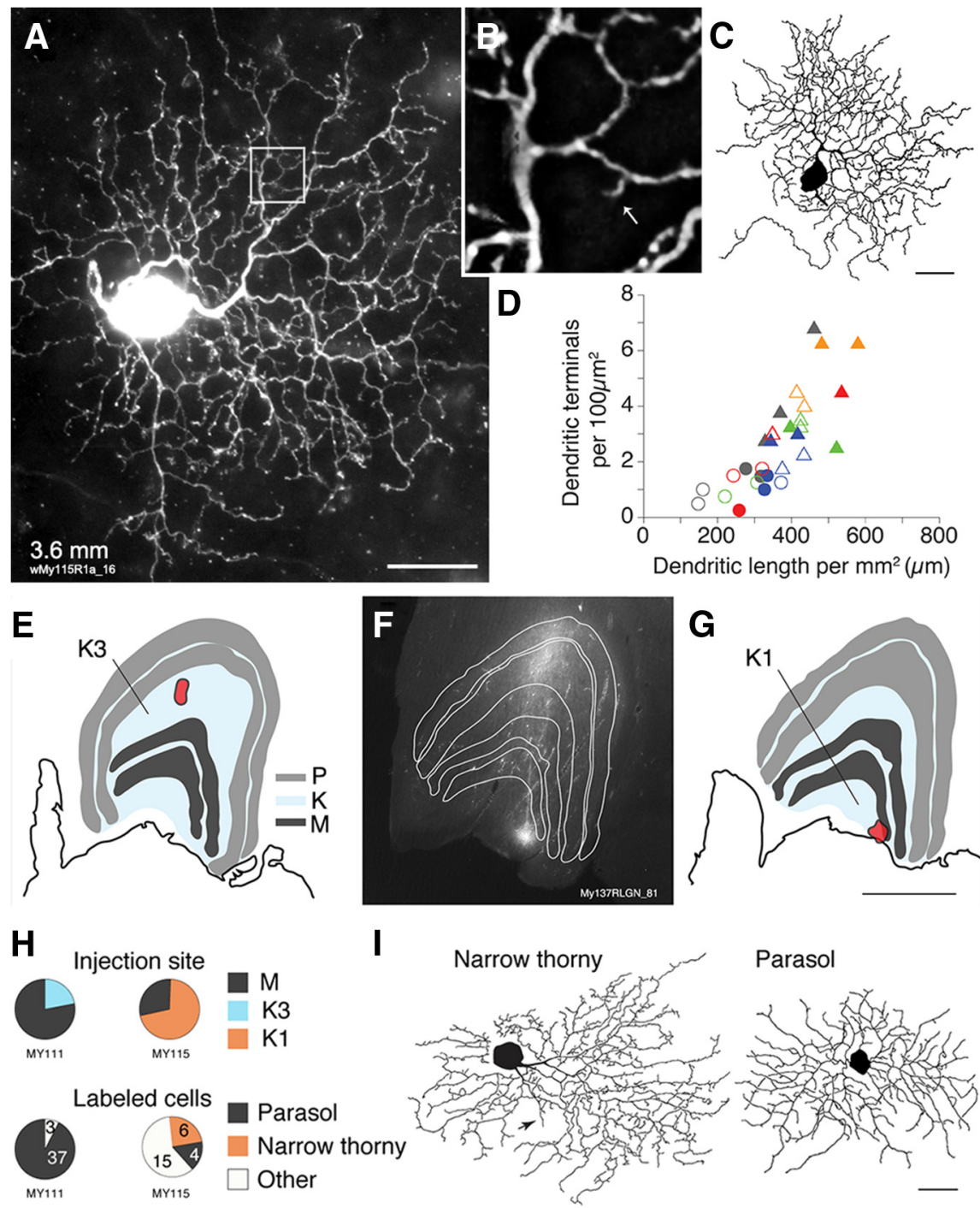

Figure 3. Narrow thorny ganglion cells labeled after injection of koniocellular layer K1. $\boldsymbol{A}$, Fluorescence micrograph of a narrow thorny cell from $3.6 \mathrm{~mm}$ eccentricity. Box indicates the region shown in $\boldsymbol{B}$, Arrow points to a dendritic thorn. $\boldsymbol{C}$, Narrow thorny cell from $3.5 \mathrm{~mm}$ eccentricity. D, Scatter plot showing morphological differences (dendritic length per area, number of dendritic thorns andor terminals per area) between narrow thorny and parasol cells. Data are based on nine narrow thorny (triangles) and seven $M$, and four K layers. $\boldsymbol{F}$, Fluorescent micrograph of a coronal section, outlines of $L G N$ are superimposed. Dense core of the injection into K1 can be seen. $\boldsymbol{E}, \boldsymbol{G}$, Reconstruction of the same LGN. Injection sites are indicated in red. $\boldsymbol{H}$, Comparison of injection sites in LGN and number of retrogradely labeled ganglion cells for two experiments. $I$, Drawings of parasol cell from $3.31 \mathrm{~mm}$ (magnocellular injection) and narrow thorny cell from $4.85 \mathrm{~mm}$ (K1 injection). Scale bars: $\boldsymbol{A}, \boldsymbol{C}, \boldsymbol{I}, 20 \mu \mathrm{m} ; \mathbf{G}, 1 \mathrm{~mm}$.

and $\mathrm{K} 2$ may be part of a primitive motion-processing pathway, which has been supplanted (or dominated) by the magnocellular pathway in course of primate evolution.

We conclude with the following speculation. It has been established that the K layers are distinct from $\mathrm{P}$ and $\mathrm{M}$ layers in their main projection sites within the primary visual cortex (Fitzpatrick et al., 1983; Solomon, 2002; Chatterjee and Callaway, 2003; Casagrande et al., 2007). Furthermore, axons from LGN layers $\mathrm{K} 1 / \mathrm{K} 2$ preferentially target more superficial cortical layers whereas axons from LGN layers K3-K6 preferentially terminate closer to the granular ( $\mathrm{M}$ and $\mathrm{P}$ recipient) layers (Xu et al., 2001; Casagrande et al., 2007). Layer K1 also projects directly to the motion-selective medial temporal area (MT), bypassing V1 (Sincich et al., 2004). These facts may implicate a role of the narrow thorny-koniocellular K1 pathway in sensitivity of MT receptive 
fields to moving stimuli following removal of V1 input in adult (Girard et al., 1992) or following neonatal lesions to V1 (Yu et al., 2013), and more broadly in the residual visual functions ("blindsight") that survive injury to primary visual cortex in adult or early life (Cowey, 2010).

\section{References}

Bleckert A, Parker ED, Kang Y, Pancaroglu R, Soto F, Lewis R, Craig AM, Wong RO (2013) Spatial relationships between GABAergic and glutamatergic synapses on the dendrites of distinct types of mouse retinal ganglion cells across development. PLoS One 8:e69612. CrossRef Medline

Boycott BB, Wässle H (1991) Morphological classification of bipolar cells of the primate retina. Eur J Neurosci 3:1069-1088. CrossRef Medline

Calkins DJ, Schein SJ, Tsukamoto Y, Sterling P (1994) M and L cones in macaque fovea connect to midget ganglion cells by different numbers of excitatory synapses. Nature 371:70-72. CrossRef Medline

Calkins DJ, Tsukamoto Y, Sterling P (1998) Microcircuitry and mosaic of a blue-yellow ganglion cell in the primate retina. J Neurosci 18:3373-3385. Medline

Casagrande VA, Xu X (2003) Parallel visual pathways: a comparative perspective. In: The vis neuroscis (Chalupa LM, Werner JS, eds), pp 494-506. Cambridge: MIT press.

Casagrande VA, Yazar F, Jones KD, Ding Y (2007) The morphology of the koniocellular axon pathway in the macaque monkey. Cereb Cortex 17: 2334-2345. CrossRef Medline

Chan TL, Martin PR, Clunas N, Grünert U (2001) Bipolar cell diversity in the primate retina: morphologic and immunocytochemical analysis of a new world monkey, the marmoset Callithrix jacchus. J Comp Neurol 437:219-239. CrossRef Medline

Chatterjee S, Callaway EM (2003) Parallel colour-opponent pathways to primary visual cortex. Nature 426:668-671. CrossRef Medline

Cowey A (2010) Visual system: how does blindsight arise? Curr Biol 20: R702-R704. CrossRef Medline

Crook JD, Peterson BB, Packer OS, Robinson FR, Gamlin PD, Troy JB, Dacey DM (2008) The smooth monostratified ganglion cell: evidence for spatial diversity in the Y-cell pathway to the lateral geniculate nucleus and superior colliculus in the macaque monkey. J Neurosci 28:12654-12671. CrossRef Medline

Dacey DM, Lee BB (1994) The "blue-on" opponent pathway in primate retina originates from a distinct bistratified ganglion cell type. Nature 367:731-735. CrossRef Medline

Dacey DM, Peterson BB, Robinson FR, Gamlin PD (2003) Fireworks in the primate retina: in vitro photodynamics reveals diverse LGN-projecting ganglion cell types. Neuron 37:15-27. CrossRef Medline

Fitzpatrick D, Itoh K, Diamond IT (1983) The laminar organization of the lateral geniculate body and the striate cortex in the squirrel monkey (Saimiri sciureus). J Neurosci 3:673-702. Medline

Ghosh KK, Goodchild AK, Sefton AE, Martin PR (1996) Morphology of retinal ganglion cells in a new world monkey, the marmoset Callithrix jacchus. J Comp Neurol 366:76-92. CrossRef Medline

Girard P, Salin PA, Bullier J (1992) Response selectivity of neurons in area MT of the macaque monkey during reversible inactivation of area V1. J Neurophysiol 67:1437-1446. Medline

Grünert U, Martin PR (1991) Rod bipolar cells in the macaque monkey retina: immunoreactivity and connectivity. J Neurosci 11:2742-2758. Medline

Grünert U, Jusuf PR, Lee SC, Nguyen DT (2011) Bipolar input to melanopsin containing ganglion cells in primate retina. Vis Neurosci 28:39-50. CrossRef Medline

Hendry SH, Reid RC (2000) The koniocellular pathway in primate vision. Annu Rev Neurosci 23:127-153. CrossRef Medline

Irvin GE, Norton TT, Sesma MA, Casagrande VA (1986) W-like response properties of interlaminar zone cells in the lateral geniculate nucleus of a primate (Galago crassicaudatus). Brain Res 362:254-270. CrossRef Medline

Jacoby RA, Marshak DW (2000) Synaptic connections of DB3 diffuse bipolar cell axons in macaque retina. J Comp Neurol 416:19-29. CrossRef Medline

Jakobs TC, Koizumi A, Masland RH (2008) The spatial distribution of glutamatergic inputs to dendrites of retinal ganglion cells. J Comp Neurol 510:221-236. CrossRef Medline

Jusuf PR, Lee SC, Grünert U (2004) Synaptic connectivity of the diffuse bipolar cell type DB6 in the inner plexiform layer of primate retina. J Comp Neurol 469:494-506. CrossRef Medline
Koizumi A, Zeck G, Ben Y, Masland RH, Jakobs TC (2007) Organotypic culture of physiologically functional adult mammalian retinas. PLoS ONE 2:e221. CrossRef Medline

Kolb H, DeKorver L (1991) Midget ganglion cells of the parafovea of the human retina: a study by electron microscopy and serial section reconstructions. J Comp Neurol 303:617-636. CrossRef Medline

Kolb H, Linberg KA, Fisher SK (1992) Neurons of the human retina: a Golgi study. J Comp Neurol 318:147-187. CrossRef Medline

Lee BB, Martin PR, Grünert U (2010) Retinal connectivity and primate vision. Prog Retin Eye Res 29:622-639. CrossRef Medline

Lee SC, Grünert U (2007) Connections of diffuse bipolar cells in primate retina are biased against S-cones. J Comp Neurol 502:126-140. CrossRef Medline

Leventhal AG, Rodieck RW, Dreher B (1981) Retinal ganglion cell classes in the old world monkey: morphology and central projections. Science 213: 1139-1142. CrossRef Medline

Martin PR, White AJ, Goodchild AK, Wilder HD, Sefton AE (1997) Evidence that blue-on cells are part of the third geniculocortical pathway in primates. Eur J Neurosci 9:1536-1541. CrossRef Medline

Morgan JL, Schubert T, Wong RO (2008) Developmental patterning of glutamatergic synapses onto retinal ganglion cells. Neural Dev 3:8. CrossRef Medline

Moritoh S, Komatsu Y, Yamamori T, Koizumi A (2013) Diversity of retinal ganglion cells identified by transient GFP transfection in organotypic tissue culture of adult marmoset monkey retina. PLoS One 8:e54667. CrossRef Medline

Percival KA, Jusuf PR, Martin PR, Grünert U (2009) Synaptic inputs onto small bistratified (blue-ON/yellow-OFF) ganglion cells in marmoset retina. J Comp Neurol 517:655-669. CrossRef Medline

Percival KA, Martin PR, Grünert U (2011) Synaptic inputs to two types of koniocellular pathway ganglion cells in marmoset retina. J Comp Neurol 519:2135-2153. CrossRef Medline

Percival KA, Martin PR, Grünert U (2013) Organisation of koniocellularprojecting ganglion cells and diffuse bipolar cells in the primate fovea. Eur J Neurosci 37:1072-1089. CrossRef Medline

Peterson BB, Dacey DM (1999) Morphology of wide-field, monostratified ganglion cells of the human retina. Vis Neurosci 16:107-120. Medline

Puthussery T, Venkataramani S, Gayet-Primo J, Smith RG, Taylor WR (2013) NaV1.1 channels in axon initial segments of bipolar cells augment input to magnocellular visual pathways in the primate retina. J Neurosci 33:16045-16059. CrossRef Medline

Sincich LC, Park KF, Wohlgemuth MJ, Horton JC (2004) Bypassing V1: a direct geniculate input to area MT. Nat Neurosci 7:1123-1128. CrossRef Medline

Solomon SG (2002) Striate cortex in dichromatic and trichromatic marmosets: neurochemical compartmentalization and geniculate input. J Comp Neurol 450:366-381. CrossRef Medline

Solomon SG, White AJ, Martin PR (2002) Extraclassical receptive field properties of parvocellular, magnocellular and koniocellular cells in the primate lateral geniculate nucleus. J Neurosci 22:338-349. Medline

Szmajda BA, Grünert U, Martin PR (2008) Retinal ganglion cell inputs to the koniocellular pathway. J Comp Neurol 510:251-268. CrossRef Medline

Tailby C, Szmajda BA, Buzás P, Lee BB, Martin PR (2008) Transmission of blue $(S)$ cone signals through the primate lateral geniculate nucleus. J Physiol 586:5947-5967. CrossRef Medline

tom Dieck S, Altrock WD, Kessels MM, Qualmann B, Regus H, Brauner D, Fejtová A, Bracko O, Gundelfinger ED, Brandstätter JH (2005) Molecular dissection of the photoreceptor ribbon synapse: physical interaction of bassoon and RIBEYE is essential for the assembly of the ribbon complex. J Cell Biol 168:825-836. CrossRef Medline

White AJ, Solomon SG, Martin PR (2001) Spatial properties of koniocellular cells in the lateral geniculate nucleus of the common marmoset, Callithrix jacchus. J Physiol 533:519-535. CrossRef Medline

Xu X, Ichida JM, Allison JD, Boyd JD, Bonds AB, Casagrande VA (2001) A comparison of koniocellular, magnocellular and parvocellular receptive field properties in the lateral geniculate nucleus of the owl monkey (Aotus trivirgatus). J Physiol 531:203-218. CrossRef Medline

Yamada ES, Bordt AS, Marshak DW (2005) Wide-field ganglion cells in macaque retinas. Vis Neurosci 22:383-393. CrossRef Medline

Yu HH, Chaplin TA, Egan GW, Reser DH, Worthy KH, Rosa MG (2013) Visually evoked responses in extrastriate area MT after lesions of striate cortex in early life. J Neurosci 33:12479-12489. CrossRef Medline 